\title{
The Mediating Effect Of Self-Efficacy on the Relationship Between Entrepreneurship Education and Entrepreneurial Intentions of University Students
}

\author{
Jacob L. Oyugi
}

\begin{abstract}
This paper has been written using data derived from a major study conducted by Oyugi (2011). The study investigated the contribution of entrepreneurship education to the development of entrepreneurial self-efficacy and intentions among university students in Uganda. The paper recognizes the development and the teaching of entrepreneurship courses in most universities in Uganda with the aim of rolling out students sufficiently equipped to become job creators. At a time when efforts are being made to address graduate unemployment through mainstream training in entrepreneurial skills in post-primary and post-secondary education, this paper provides timely guidance on the entrepreneurial curriculum. It proposes a quantitative analysis in which entrepreneurship education and entrepreneurial selfefficacy are key to developing entrepreneurial intentions of students. To investigate this, two hypotheses were formulated. Data was collected by means of a mail survey questionnaire completed by students, randomly selected from a sampling frame of third year students, who had training in entrepreneurship course. The findings revealed that significant relationships exist between entrepreneurship education and entrepreneurial intention, while self-efficacy was found to partially mediate the entrepreneurship education and entrepreneurial intention.

Keywords: entrepreneurship education, entrepreneurial self-efficacy, entrepreneurial intention, mediation, university students.
\end{abstract}

\section{INTRODUCTION}

The paper set out to investigate and test the statistical relationship between entrepreneurial intentions of students and entrepreneurship education in

1 Jacob L. Oyugi, Ph.D., School of Management and Entrepreneurship, Kyambogo University, Kampala - Uganda. P.O Box 1, Kyambogo-Uganda. E-mail: joyugi@kyu.ac.ug. 
universities in Uganda. In view of the fact that a bigger study considered course objectives and method of course delivery together with course content, this paper focuses on the mediating effect of self-efficacy on the relationship between entrepreneurship education and entrepreneurial intentions. One of the objectives of the PhD thesis, therefore, was to examine the mediation of self-efficacy between entrepreneurship education and entrepreneurship intentions of university students. Specifically, this study had two objectives (1) determining the significant relationship between entrepreneurship education and entrepreneurial intentions, and (2) determining the mediating effect of entrepreneurial self-efficacy on the relationship between entrepreneurship education and entrepreneurial intentions among university students.

The paper starts by presenting the literature review, followed by methodology. Thirdly, the results are presented and discussed. The fourth part draws conclusion. Finally, the paper highlights the limitations of the study.

\section{LITERATURE REVIEW}

\section{Entrepreneurial self-efficacy}

This section covers the underpinning theory of self-efficacy, and helps to explain why it is important to develop entrepreneurship skills. To increase levels of entrepreneurship motivation, it is proposed that it is essential that entrepreneurship education programme influence self-efficacy of individuals so that they learn and persist in the pursuit of entrepreneurship (Lucas and Cooper, 2004).

Self-efficacy as a construct is conceived by Bandura (1986) as one's judgment of ability to execute an action, and is therefore a largely perceived construct. This construct is established as a reliable predictor of a wide variety of goal directed behaviors. Chen, Greene and Crick (1998, after: Lee, 2005) defined self-efficacy in the context of entrepreneurship as the strength of a person's belief that he or she is capable of successfully performing the various roles and tasks of entrepreneurship. The authors reported that selfefficacy is positively related to one's intention in setting up a business.

Krueger and Dickson $(1994$, p.94) postulated that high levels of self-efficacy are associated with strategic risk taking while Krueger et al (2000) argued that self-efficacy is a critical antecedent of entrepreneurial intent. Individuals with high self-efficacy have more intrinsic interests in entrepreneurial tasks, and are more willing to make an effort and show persistence when faced with obstacles and setbacks. Self-efficacy influences the choices we make, the effort one puts in, how long one persists at a task and how one feels 
about it. If a person believes that the performance of a certain task is within their capability, he/she will act, even if the task is difficult because he/she perceives the successful completion of the task as a feasible goal given the belief in self. Self-efficacy is therefore related to perceptions of feasibility. To this extent self-efficacy mediates entrepreneurial intentions (Zhao, Seibert and Hills, 2005) which are determined by perceptions of feasibility and desirability.

Self-efficacy develops from mastery of experience (enactive mastery) or task accomplishment, vicarious experience (from observing others), verbal persuasion (or encouragement) as well as management of emotional states (Boyd and Vozikis, 1994). In the same way Bandura (1997) asserts that people's conceptions about themselves and the nature of things are developed and verified through four different processes: direct experience, vicarious experience, judgment voiced by others, and derivation of further knowledge by using rules of inference.

Empirical researches such as those by Cox, Mueller, and Moss (2002, 2003) have generated a great number of studies that demonstrate the positive relationship between self-efficacy and different motivational and behavioral outcomes in clinical, educational, and organizational settings. Selfefficacy has also become an important construct in behavioral management and Bandura (1982) defines self-efficacy as people's judgments of their capabilities to organize and execute courses of action required to attain designated types of performance.

As affirmed previously, self-efficacy is linked to initiating and persisting at behaviors under high uncertainty, to setting higher goals and to reducing threat rigidity (Bandura, 1986). Although many studies have found a positive relationship between self-efficacy and performance, studies such as Vancouver (2002) found a strong positive correlation between self-efficacy and performance, at the person level of analysis, yet at a within person, across time level of analysis, self-efficacy is negatively related to subsequent performance. Unlike personality traits self-efficacy can be developed through training and modeling. Efficacy judgments are tasks specific and regulate behaviour by determining task choices, effort and persistence. Self-efficacy also facilitates learning and task performance particularly early in the learning process and can also change as a result of learning, experience and feedback (Gist and Mitchell, 1992).

The foregoing literature explains the relationship between self-efficacy, beliefs and intentions. The explanation is generally on entrepreneurial behavior regardless of educational status. Bandura (1997) on the other hand, enumerates sources of self-efficacy and on close examination it does not say much on entrepreneurship education as an academic discipline which could 
be considered a source of self-efficacy. It does not state how entrepreneurship education could be linked to self-efficacy and entrepreneurial intentions of university students. The explanation, therefore, leaves a gap that this study was set to fill.

\section{Entrepreneurship education and self-efficacy}

To make a decision to start a venture requires confidence and self-belief that an individual or group of potential founders have in their ability to undertake successfully the many sub-activities that are required. Self-efficacy is central to the willingness to act in an entrepreneurial way, to identify and seize opportunities. High and low levels of self-efficacy have serious consequences for an individual's belief in the ability to perform in a range of situations. High levels of self-efficacy have been linked to various behaviors such as innovation and opportunity recognition in entrepreneurship (Ardichvili et al. 2003).

A person's willingness to act is influenced by the perceived abilities and skills with respect to that area of activity. Several authors (Gorman, 1997; Kolvereid and Moen, 1997; Noel, 2001; Tkachev and Kolvereid, 1999; Varela and Jimenez, 2001) have shown that there is a significant relationship between entrepreneurial education and the propensity of becoming an entrepreneur. An observation which has been confirmed by Noel $(2001$, p.10) shows that students who graduated in entrepreneurship reached higher scores in entrepreneurial intention and entrepreneurial self-efficacy than students who graduated in other disciplines. Similarly, Varela and Jimenez (2001) indicate that there is a correlation between a university's investment in the promotion of entrepreneurship and the percentage of students becoming entrepreneurs.

However, the literature seems to have paid limited attention to the importance of specific educational variables, such as curriculum design, teaching and assessment. There is insufficient research regarding the outcomes of entrepreneurship education which link it to self-efficacy and intention. This study sought to fill the gap by linking entrepreneurship education, selfefficacy and entrepreneurial intentions. Based on the literature, the following hypothesis was formulated that

there is a statistically significant relationship between entrepreneurship education and self-efficacy.

\section{Self-efficacy linked to entrepreneurship}

As the literature review has indicated, self-efficacy is anchored in a model of entrepreneurial potential and linked to entrepreneurial intention. The notion of entrepreneurial potential seems causally prior to intentions (Krueger 
and Brazeal, 1994), one may have great potential without corresponding intentions. Krueger and Brazeal (1994) offer a model of potential, which situates Shapero's model within the context of the intentions process. One important conclusion by way of their model remains the position of perceived feasibility (self-efficacy). Chen, Greene and Crick (1998, after: De Noble et al, 2000) assert that self-efficacy has a number of practical and theoretical implications for entrepreneurial success because initiating a new venture requires unique skills and mindsets, which may be far different from those required of managers in a fully established organization.

Chen, et al (1998) propose entrepreneurial self-efficacy construct to predict likelihood of individual being an entrepreneur, that is, entrepreneurial self-efficacy refers to strengths of a person's belief of being capable of successfully performing various roles and tasks of an entrepreneur. Those with high entrepreneurial self-efficacy tend to assess the environment as more opportunistic rather than fraught with risks; they believe in ability to influence achievement of goals; and they perceive a low probability of failure. Chen, et al (1998) study based on two-surveys found that entrepreneurial selfefficacy was positively related to the intention to set up one's own business. As interpreted by Chen, et al (1998, p.295), the self-efficacy perspective is highly appropriate for the study of the entrepreneur. Based on the review of the literature, the following hypothesis was postulated:

Self-efficacy mediates the relationship between entrepreneurship education and entrepreneurial intention among university students.

\section{METHODOLOGY}

\section{Study design}

This research employed a mixed methodology approach using quantitative and qualitative design which is highly grounded in the philosophy of social sciences literature. The selection of the design is in line with (Creswell, 2003). The quantitative data was to establish the relationship and its magnitude between entrepreneurship education, self efficacy and entrepreneurial intentions of university students. On the other hand, the research methodology relied on qualitative data where the body of data consisted of texts and narration to help in explaining what was happening in as far as entrepreneurship education in the selected universities was concerned. The choice to collect the data using a combination of methods was based on the idea of triangulation for creating a richer and deeper understanding of the phenomenon as well as increase the validity of the research findings. 


\section{Target population}

Population of interests for the study were university students in their third year (final year of study in Uganda's university system) who were enrolled into the business programme and had studied entrepreneurship course. These students were targeted due to their enrolment into business programmes which provide indicators that their career interests are skewed towards business related fields. Therefore they would likely choose to become entrepreneurs. The target universities were Makerere Business School, Kampala International University, and Uganda Martyrs University. The three universities were targeted because, by the time this study started, they had been teaching and examining business and entrepreneurship courses for more than five years. A total of 2,223 formed the student population across the three universities. Out of this a sample size of 281 students were randomly selected and used.

\section{Testing for mediation}

In order to test the mediation effect of self efficacy, Baron and Kenny (1986) four-step regression method was used. Baron and Kenny (1986) proposed a four step approach in which several regression analyses are conducted and significance of the coefficients is examined at each step. Using an illustration, mediation can be depicted in the following way:

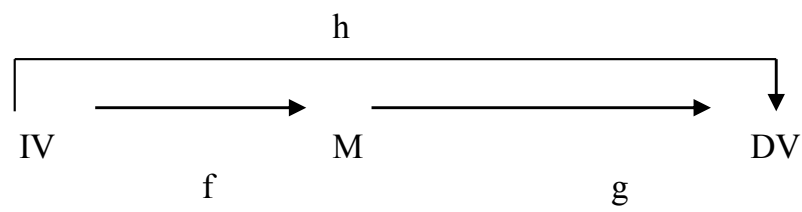

Where IV is the independent variable, $M$ is the mediating variable, DV is the dependent variable. The paths (coefficients) are denoted by $f, g$ and $h$. A summary of the four steps are presented in Table 1.

Table 1. A summary of the four-step approach of testing for mediation

\begin{tabular}{lll}
\hline & Analysis model & Visual Depiction \\
\hline Step 1 & $\begin{array}{l}\text { A simple regression analysis with } \mathrm{X}(\mathrm{IV}) \\
\text { predicting } \mathrm{Y}(\mathrm{DV}) \text { to test for path } \mathrm{h} \text { alone } \\
\mathrm{Y}=\alpha+\beta \mathrm{X}+\varepsilon\end{array}$ & \\
Step 2 & $\begin{array}{l}\text { A simple regression analysis with } \mathrm{X} \text { predicting } \\
\mathrm{M} \text { to test for path } \mathrm{f}, \mathrm{M}=\alpha+\beta \mathrm{X}+\varepsilon\end{array}$ & $\mathrm{X} \longrightarrow \mathrm{M}$
\end{tabular}


Step 3

Step 4
A simple regression analysis with $M$ predicting $Y$ to test the significance of path $g$ alone, $Y=\alpha$ $+\beta_{1} M+\varepsilon$

A multiple regression analysis with $X$ and $M$ predicting $\mathrm{Y}$ to test paths $\mathrm{h}$ and $\mathrm{g}$ respectively, $Y=\alpha+\beta_{1} X+\beta_{2} M+\varepsilon$
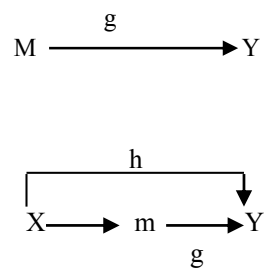

Source: Baron and Kenny (1986).

In Table 1, the purpose of steps $1-3$ was to establish that zero-order relationships among the variables exist. If one or more of these relationships are non-significant, researchers usually conclude that mediation is not possible or likely (although this is not always true, Mackinnon, Fairchild, \& Fritz, 2007). A significant relationship from steps $1-3$, led to step 4. Step 4 model, was necessary to ascertain if a full or partial mediation occurred. According to Baron and Kenny (1986) a full mediation occurs if the effect of mediating variable (self-efficacy, path g) remains significant after controlling for independent variable (entrepreneurship education). On the other hand, a partial mediation is deemed to have occurred if the relationship between the independent variable and the dependent variable is still significant after controlling for the effects of the intervening variable (that is, both entrepreneurship education construct and self-efficacy significantly predict entrepreneurial intentions).

\section{Preparation and data collection procedures}

Research instruments in the form of questionnaires were constructed and administered in English since English is the official language of instruction in all universities in Uganda. A pre-test of the survey instrument was conducted at Uganda Christian University, Mukono and Nkumba University, Entebbe, using the final year students. A total of 30 of the final year students were selected in both institutions to participate in the pre-test. Mukono and Nkumba universities were selected for the pre-test because they were not included in the final sample for the actual data collection. The pre-test was basically for further validation in the context of the study as well as determining and correcting possible errors.

Basing on the result of the pre-test, 5 core dimensions were selected and incorporated into the questionnaire for data collection. The detail of the core dimensions and their constructs were as follows: A) Personal Data (gender, age, level and nature of entrepreneurship education offered); B) Contents of Entrepreneurship Education (asking what students had achieved as a result 
of the content of entrepreneurship in terms of opportunity seeking behavior, coping with uncertainty, motivation, capability of setting an organization, capacity to see problem as opportunity); C) Objectives (the extent to which students perceive the objectives of entrepreneurship programmes to have been attained in relation to the development of their entrepreneurial intention in terms of: providing specialist knowledge and skills about how to start and manage small businesses, providing specialist knowledge and skills in the development and designing of feasible business plans, creating all round entrepreneurs who can make sound managerial, financial and marketing decisions, providing specialist knowledge and skills about how to develop small businesses and see them grow through medium to large firms); D) Methodology (the extent to which students perceive the methods of entrepreneurship education to have contributed to the development of their entrepreneurial intention) and E) Self-efficacy variable (ability to: achieve goals, accompany a difficult tasks, obtain outcomes that are important, overcome many challenges, set and meet market share goal, engage in new ideas and venturing, reduce risks); Entrepreneurial Intention (asking students whether students had specific ideas for a new business, began taking steps toward starting a business, detailed plan for a new venture, willing to act soon on an opportunity).

All the items were rated on a four-point Likert-like scale ranging from "1" "Not at all" to "4" "Large extent" depending on the perceived degree of confidence of the individual respondent. The students' intentions to start their own businesses were also measured using a 12-item dimension built on Krueger's et al (1999) validated questionnaire. All the 12 items were measured based on a 4-point rating scale ranging from " 1 " Not at all" to " 4 " "Large extent". Besides the questionnaire, other data collection tools, such as interview guide and focus group guide, were prepared.

\section{METHOdS OF DATA COLLECTION}

The study based itself on the primary data and secondary data sources. The primary data was required to provide source of new information for the research in progress. On the other hand, the secondary data was necessary to search existing sources of information to complement the primary data as well as to avoid replication of possibly expensive and time-consuming data collection. Based on the study design and the philosophical assumptions, the second dichotomy was that of quantitative and qualitative methods. The quantitative method was to generate numerical data since a large number of cases was involved and also to allow for generalization to a wider population. 
On the other hand, the qualitative method was generally used where numerical data was not easy to generate and where a small number of cases was involved. To generate the quantitative and qualitative data, the instruments used consisted of a questionnaire, interview guide and focus group guide. The procedures of administering data collection are presented in the following sub-sections.

\section{The questionnaire}

Since one of the objectives of this study was to explain entrepreneurship intention as a dependent variable and self-efficacy as a mediating variable, there was a need to identify valid and reliable measures of the variables. This was done through a literature review of previous studies such as that of Chen et al (1998) and that of Krueger et al (1999). These two studies were based on validated measures of self-efficacy and entrepreneurial intention and, therefore, they were adapted for the purpose of this study.

The questionnaire was designed with further help of entrepreneurial intentions questionnaires validated by earlier researchers like Krueger, et al (2000). The questionnaire was divided into parts, according to the variables of the study as already explained under the section on data collection procedure. The key respondents to the questionnaire were the final year students in the selected universities who had done courses in entrepreneurship. These were selected because they were the recipient of the knowledge of entrepreneurship education.

The questionnaire was subject to validity and reliability test for the purpose of data quality control.

\section{Validity test}

A Content Validity Index (CVI) was computed for this purpose using the formula as follows.

Content validity index $(\mathrm{CVI})=\frac{\text { Number of items declared valid }}{\text { Total number of items on the questionnaire }}$

From the pre-test result and view of the supervisor, 91 items out of 112 items were declared valid. The validity index was approximately 0.8 which compares very well with 0.7 which Amin (2005) postulates that if the content validity index is greater than 0.7 , it means that the questions are relevant to the study variables. 


\section{Reliability test}

Cronbach's (1994) alpha coefficient test was used to test the reliability of the instrument. Nunnaly (1978) stated that if the Cronbach's alpha coefficient is 0.5 , it is sufficient value, while 0.7 is a more reasonable value. The reliability test was carried out using SPSS package for the entire instrument. The Cronbach's alpha coefficient was 0.9 , implying very high reliability and consistency.

However, to get a clear picture, reliability test for each measure under the different section of the questionnaire was tested using the same method. Table 2 presents the Cronbach's coefficient alpha reliability measure of internal consistency for each sub-scale.

Table 2. Reliability test results for the various measures

\begin{tabular}{lcc}
\hline Measure & Number of items & $\begin{array}{c}\text { Cronbach's alpha } \\
\text { coefficient }\end{array}$ \\
\hline Content of entrepreneurship & 7 & 0.71 \\
Objectives & 8 & 0.76 \\
Teaching method & 12 & 0.88 \\
Assessment and Feedback & 4 & 0.87 \\
Self-efficacy measures & 15 & 0.92 \\
Intentions measures & 19 & 0.83 \\
Readiness to be entrepreneurial & 7 & 0.72 \\
Intervening variables & 14 & 0.80 \\
\hline Total Number of items & 91 & 0.92 \\
\hline
\end{tabular}

From Table 2, all sections passed the reliability tests with content of entrepreneurship measures having the lowest coefficient (0.71). However, the average Cronbach's alpha was 0.81 , which reaffirms that each section was reliable in as far as measure of entrepreneurship was concerned.

\section{ANALYSIS}

\section{Response rate}

Quantitative data was collected by way of self-administered questionnaires designed for student respondents. The specific breakout of the composition of the net delivery and net response are broken out as in Tables 3 and 4 . 
Table 3. Composition of net delivery

\begin{tabular}{lcc}
\hline Item & No. of respondents & Percentage \\
\hline Questionnaires Issued & 281 & $100 \%$ \\
Questionnaires not returned & 20 & $7.1 \%$ \\
Net Delivery & 261 & $92.9 \%$ \\
\hline
\end{tabular}

Table 3 shows that a total of 281 survey questionnaires were delivered. Of these, 20 (7.1\%) were not returned. This left a net delivery of 261 (92.9\%). The composition of the net response is indicated in Table 4.

Table 4. Composition of net response

\begin{tabular}{lcc}
\hline Item & No. of respondents & Percentage \\
\hline Questionnaires Issued & 281 & $100 \%$ \\
Responses Received & 261 & $97.9 \%$ \\
Incomplete(discarded) Responses & 6 & $2.1 \%$ \\
Net Responses & 255 & $90.7 \%$ \\
\hline
\end{tabular}

Table 4 shows that out of the 281 questionnaires delivered, 261 (97.9\%) questionnaires were returned, out of which $6(2.1 \%)$ were incomplete and, therefore, discarded. This is because most of therespondents had failed to fill more than $75 \%$ of the questionnaires. The subsequent analysis is based on the net responses of $255(90.7 \%)$ whose respondent characteristics are explained in the following section.

\section{Characteristics of the sample}

The respondents whose characteristics are explained below were drawn from three universities in Uganda. These were Makerere University Business School (MUBS), Uganda Martyrs University (UMU) and Kampala International University (KIU). All the three universities teach entrepreneurship courses. The characteristics of the sample under study covered gender, age, level of study and nature of entrepreneurship course. Frequency distributions were obtained for all the personal data. Table 5 shows distribution of Gender of the respondents.

Table 5. Distribution of gender of respondents

\begin{tabular}{lcc}
\hline Sex & Frequency & Percent \\
\hline Male & 139 & 54.5 \\
Female & 116 & 45.5 \\
\hline Total & 255 & 100.0 \\
\hline
\end{tabular}


As can be observed from Table 5, gender was considered important in this study because it may have an effect on self - efficacy and intentions. Researchers have shown differences in self - efficacy of female entrepreneurs and male entrepreneurs. Table 4 shows that $54.5 \%$ of the respondents were male and $45.5 \%$ of them were female. The result indicates that there was small difference $(9 \%)$ in the number of male and female students studying entrepreneurship. Table 6 shows the distribution of age of the respondents.

Table 6. Distribution of age of respondents

\begin{tabular}{lcc}
\hline Age range & Frequency & Percent \\
\hline under 20 years & 1 & .4 \\
$20-24$ years & 185 & 72.5 \\
$25-29$ years & 56 & 22.0 \\
$30-34$ years & 9 & 3.5 \\
$40-49$ years & 3 & 1.2 \\
50 years and above & 1 & .4 \\
\hline Total & 255 & 100.0 \\
\hline
\end{tabular}

Analysis of the age distribution from Table 6 , shows that the majority $(72.5 \%)$ of the university students interviewed were aged between 20 to 24 years. Out of the $255,22.0 \%$ of them were aged between (25-29) percent. These age brackets are typical of university students in Uganda given the fact that the majority join the university at the age of 19 to 20 years. The extreme age brackets are not uncommon given the fact that mature entrance and Diploma entry schemes are available avenues for university admissions in Uganda. This Table also indicates that there was one student below the age of 20 . The distribution of age of the respondents confirms that they are of the right age to be at the university and, therefore, they are no longer minors. This implies that the respondents had a high level of comprehension for the items in the questionnaires. However, this research focused on the entrepreneurial self - efficacy and intentions of these categories of students. The question is whether such young people develop confidence to be entrepreneurial since at such a young age, they may be impatient to start and grow a business.

The nature of study of entrepreneurship courses was also considered important and this is presented in Table 7.

Table 7. Distribution of nature of study of entrepreneurship

\begin{tabular}{lcc}
\hline Nature & Frequency & Percent \\
\hline Course unit & 223 & 87.5
\end{tabular}




\begin{tabular}{lcc} 
Topic & 12 & 4.7 \\
Programme & 19 & 7.4 \\
Audited course & 1 & .4 \\
\hline Total & 255 & 100.0 \\
\hline
\end{tabular}

Table 7 reveals that in most universities, entrepreneurship education is taken as a course unit since $87.5 \%$ of the interviewed students reported so. Those who offer it as a topic were $4.7 \%$. A total of $19(7.4 \%)$ take it as a programme and $0.4 \%$ of them take it as an audited course. Although it is correct to report that the majority $223(87.5 \%)$ take entrepreneurship as a course unit, it is not correct to say that only $19(7.4 \%)$ take it as a programme. This argument is supported by the fact that Makerere University Business School (MUBS) registered a total of 153 third year students (2008/2009) for Bachelor of Entrepreneurship and Small Business Management. This is a reflection that most students did not understand the difference between a programme and a course unit. Despite this misconception, the importance of the nature of study is that those who take entrepreneurship education as course unit usually have less content and time compared to those who offer it as a programme. This means that those who took it as course unit were likely to have less confidence while those who took it as a programme had more time to develop their self - efficacy, hence likely to be more confident. This sentiment was common among those who were interviewed. Most of those interviewed did entrepreneurship as a course unit and all of them expressed concern that the time was too short. It was done in one semester ( 2 hours a week), limited in scope and most of the lectures were rushed through giving them very little time to internalize the course. Given such a scenario, it is very unlikely that entrepreneurship education contributed to the development of self - efficacy and entrepreneurial intentions of such students.

\section{THE STUDY VARIABLES}

The ultimate dependent variable for this study was entrepreneurial intention. However, for somebody to have entrepreneurial intention there must be entrepreneurial self - efficacy. Therefore, this section is examining the mediating effect that entrepreneurial self - efficacy has for somebody to have entrepreneurial intention. In order to test for the presence of mediation and the subsequent hypothesis, an assessment was made by comparing the results of correlations. This was done so as to eliminate the possibility of doubt arising from the dangers of correlation research where significant relationship between two variables is actually due to a variable that was not considered. There was need to ascertain if a full mediation occurred. 
According to Baron and Kenny (1986) a full mediation occurs if the effect of mediating variable (self-efficacy) remains significant after controlling for independent variable (entrepreneurship constructs). On the other hand, a partial mediation is deemed to have occurred if the relationship between the independent variable and the dependent variable is still significant after controlling for the effects of the intervening variable (that is, both entrepreneurship education construct and self-efficacy significantly predict entrepreneurial intentions).

Table 8 summarizes the results of the correlations. The correlation coefficient between self- efficacy and intention is $(r=0.418, p<0.01)$; while the correlation coefficient between self - efficacy and entrepreneurship education is ( $r=0.672, p<0.01)$; and the correlation coefficient between entrepreneurship education and intention is $(r=0.464, p<0.01)$.

Table 8. Correlations between self - efficacy, entrepreneurship education andentrepreneurship intentions

\begin{tabular}{llll}
\hline Self - Efficacy & 1.000 & & \\
Entrepreneurship Education & $.672^{* *}$ & 1.000 & \\
Entrep.Intentions & $.418^{* *}$ & $.464^{* *}$ & 1.000 \\
\hline
\end{tabular}

$* * p<.01$

The result in Table 8 shows a statistically significant relationship between entrepreneurship education and self - efficacy. This finding is consistent with the findings of Kolvereid and Moen (1997); Gorman (1997); Noel (2001); Tkachev and Kolvereid (1999); Varela and Jimenez (2001) which reported a statistically significant relationship between entrepreneurial education and the propensity to become an entrepreneur. The findings have further been supported by the result of interview with the students who agreed that they had gained more confidence from doing the course in entrepreneurship than before. One of the students narrated how confident he had become after taking the course ...

I am very confident of myself because I know where to start from; I know which project to go for...' Another interviewee answered 'Yes, I have developed the confidence...I have been with the people doing business. Perhaps that is why I have the confidence.

The student's response cited above is consistent with the statement by Linan (2006) that knowing an entrepreneur, and being familiar with the business environment, makes students more confident about their own capacity of becoming entrepreneurs. All these findings confirm that entrepreneurship education can contribute to developing entrepreneurial 
self efficacy of the students, especially where the learner is exposed to the real situation. Further investigation was carried out to establish whether they had the intention to engage in creating jobs for themselves now that they had completed their study. One of the interview questions in connection with their intention was: Assuming you were offered two alternatives, 1. an offer for an executive employment in a reputable firm and 2. an offer of an attractive sum of money for a start up capital for a business, which one would you choose? Although one would expect them to go for the second option, the findings indicate that most of them opted for executive employment. Some of the reasons for going for employment were expressed as follows:

At my level I would start with reputable jobs and think of a business later...think of getting enough capital first, that is, have something first before I receive contribution from others.' Another student answered. I would prefer to start from a firm since I will be innovative, creative, before starting. I may not feel the pain if I am given money...Business risk such as Government policy, tax, procedures and so on.

These findings explain why there is a moderate correlation between entrepreneurship education and entrepreneurial intentions though statistically significant $(r=0.464, p<0.01)$. This implies that even if the students had received entrepreneurship education, their intentions to start a business still remain doubtful. However, the results of the correlation indicated a statistically positive significant relationship between self - efficacy and intention implying that self - efficacy has an effect on intentions. Self - efficacy, on the other hand, is influenced by education. It was therefore concluded from the correlation results that self-efficacy mediates between entrepreneurship education and intentions of the students. This means, if self-efficacy is increased, intention to become entrepreneurs also increases though not necessarily in the same proportion. Thus, it is proposed that self - efficacy is an important variable in measuring the level of entrepreneurial intention, as well as the likelihood of entrepreneurial action.

In order to test the mediation effect of self-efficacy, Baron and Kenny (1986) four-step regression method, as explained under methodology section, was used. In step 1, a simple regression analysis was carried out with entrepreneurship education predicting entrepreneurial intention. The results are shown in Tables 9 and 10. The model also produces Durban-Watson test statistics value of 1.863 . Since this value is greater than 1 and less than 3 , it shows that the model is well specified. 
Table 9. Regression model with entrepreneurial intentions as dependent variable

Change Statistics

Std. Error $\quad \mathbf{R}$

$\mathbf{R}$ Adjusted of the Square

Sig. F Durbin-

Model $R$ square $R$ Square Estimate Change $F$ Change df1 df2 Change Watson

$\begin{array}{lllllllllll}1 & .418^{\mathrm{a}} & .175 & .163 & .20261 & .175 & 14.412 & 2 & 136 & .000 & 1.885\end{array}$

a. Predictors: (Constant), Entrepreneurship Education, Self Efficacy

a. Dependent Variable: Entrepreneurial Intentions

The ANOVA, Table 10, indicates that the model fits and there is linearity between entrepreneurship and entrepreneurial intention (Sig.F $=0.002$ ) shown in the tables.

Table 10. ANOVA

\begin{tabular}{lccccc}
\hline Model & $\begin{array}{c}\text { Sum of } \\
\text { Squares }\end{array}$ & Df & Mean Square & F & Sig. \\
\hline Regression & .459 & 1 & .459 & 9.974 & $.002^{\text {a }}$ \\
Residual & 6.307 & 137 & .046 & & \\
Total & 6.766 & 138 & & & \\
\hline
\end{tabular}

a. Predictors: (Constant), Entrepreneurship Education

b. Dependent Variable: Entrepreneurial Intentions

The coefficients table indicates a significant positive effect of entrepreneurship education on entrepreneurial intention. This means that entrepreneurship education alone explains or contributes $26.1 \%$ of the variance in entrepreneurial intention as indicated by the Adjusted $R$ square with Beta coefficient $(\beta=0.464)$ indicating a moderate contribution to the development of entrepreneurial intention as shown in Table 11.

Table 11. Relationship between entrepreneurship education and entrepreneurial intention

\begin{tabular}{|c|c|c|c|c|c|c|c|c|c|c|}
\hline \multirow[b]{2}{*}{ Model } & \multicolumn{2}{|c|}{$\begin{array}{l}\text { Unstandardized } \\
\text { Coefficients }\end{array}$} & \multirow{2}{*}{$\begin{array}{l}\text { Standard- } \\
\text { ized Coef- } \\
\text { ficients } \\
\text { Beta } \\
\end{array}$} & \multirow[b]{2}{*}{1} & \multirow[b]{2}{*}{ Sig. } & \multirow[b]{2}{*}{$\begin{array}{l}\text { Zero- } \\
\text { order }\end{array}$} & \multicolumn{2}{|c|}{ Correlations } & \multicolumn{2}{|c|}{$\begin{array}{c}\text { Collinearity } \\
\text { Statistics }\end{array}$} \\
\hline & B & Std. Error & & & & & $\begin{array}{l}\text { Par- } \\
\text { tial }\end{array}$ & Part & $\begin{array}{l}\text { Toler- } \\
\text { ance }\end{array}$ & VIF \\
\hline (Constant) & .491 & .018 & & 26.878 & .000 & & & & & \\
\hline Self Efficacy & .139 & .033 & .409 & 4.200 & .000 & .418 & .339 & .327 & .638 & 1.566 \\
\hline $\begin{array}{l}\text { Entrepreneur- } \\
\text { ship Educa- } \\
\text { tion }\end{array}$ & .005 & .034 & .014 & .147 & .883 & .261 & .013 & .011 & .638 & 1.566 \\
\hline
\end{tabular}

a. Dependent Variable: Entrepreneurial Intentions

Entrepreneurship: Intentions, Institutional and Process,

Anna Ujwary-Gil, Krzysztof Klincewicz (Ed.) 
In Step 2, a simple regression analysis was run with entrepreneurship education predicting self - efficacy. The results show a positive linear relationship between entrepreneurship education and entrepreneurial intention and also positive significant effect of entrepreneurship education on entrepreneurial intention. The entrepreneurship education significantly contributes $44.9 \%$ to the development of entrepreneurial self - efficacy. This contribution is high as indicated by Beta coefficient ( $\beta=0.672$ or $67.2 \%$ ) as in Table 12 .

Table 12. Relationship between entrepreneurship education and self - efficacy

\begin{tabular}{|c|c|c|c|c|c|c|c|c|c|}
\hline \multirow[b]{2}{*}{ Model } & \multicolumn{2}{|c|}{$\begin{array}{l}\text { Unstandardized } \\
\text { Coefficients }\end{array}$} & \multirow{2}{*}{$\begin{array}{c}\text { Standard- } \\
\text { ized Coef- } \\
\text { ficients } \\
\text { Beta } \\
\end{array}$} & \multirow[b]{2}{*}{$T$} & \multirow[b]{2}{*}{ Sig. } & \multirow[b]{2}{*}{$\begin{array}{l}\text { Zero- } \\
\text { order }\end{array}$} & \multirow{2}{*}{$\begin{array}{l}\text { Correla- } \\
\text { tions } \\
\text { Par- } \\
\text { tial Part }\end{array}$} & \multicolumn{2}{|c|}{$\begin{array}{c}\text { Collinearity } \\
\text { Statistics }\end{array}$} \\
\hline & B & $\begin{array}{l}\text { Std. } \\
\text { Error }\end{array}$ & & & & & & $\begin{array}{l}\text { Toler- } \\
\text { ance }\end{array}$ & VIF \\
\hline (Constant) & $\begin{array}{c}3.013 \mathrm{E}- \\
17\end{array}$ & .033 & & .000 & 1.000 & & & & \\
\hline $\begin{array}{l}\text { Entrepreneur- } \\
\text { ship Education }\end{array}$ & .673 & .047 & .672 & 14.423 & .000 & .672 & .672 .672 & 1.000 & 1.000 \\
\hline
\end{tabular}

a. Dependent Variable: Self Efficacy

The result in Table 12 is partly supported by the fact that $90 \%$ of the students interviewed agreed that they had gained confidence in themselves more than before the course. For example, ability to see more opportunities than before. One female respondent, when asked whether she had the confidence to start and grow a business responded, "Yes, I did gain confidence. I really believe I can do something, for example, I can start a very nice Hair Saloon." The student's response is also in line with the findings of other researches (Kolvereid and Moen, 1997; Gorman, 1997; Varela and Jimenez, 2001) which showed that there was a significant relationship between entrepreneurship education and the propensity to become an entrepreneur.

The coefficients table produces the VIF and the Tolerance values of less than 10 and greater than 0.2 respectively indicating no multi collinearity within the data.

The collinearity diagnostics results indicate the Eigen value of 1.000 and the condition index of 1.000 as well, all supporting the fact that the model fits and there is no collinearity between entrepreneurship education and self efficacy. The result is indicated in Table 13.

Table 13. Collinearity Diagnostics: entrepreneurship education and self - efficacy

\begin{tabular}{cccccc}
\hline \multirow{2}{*}{ Model } & Dimension & Eigenvalue & $\begin{array}{c}\text { Condition } \\
\text { Index }\end{array}$ & \multicolumn{2}{c}{ Variance Proportions } \\
(Constant) & Entrepreneurship Education \\
\hline 1 & 1 & 1.000 & 1.000 & 1.00 & .00 \\
& 2 & 1.000 & 1.000 & .00 & 1.00 \\
\hline
\end{tabular}

a. Dependent Variable: Self -Efficacy 
Another simple regression analysis was performed in step 3 with entrepreneurial self - efficacy predicting entrepreneurial intention. The results from the model summary table and the coefficient table indicate that there is a positive significant relationship between self - efficacy and intention $(r=0.418, p<0.01)$. This is indicated in Table 14.

Table 14. Relationship between self - efficacy and entrepreneurial intentions

\begin{tabular}{|c|c|c|c|c|c|c|c|c|c|c|}
\hline & \multicolumn{2}{|c|}{$\begin{array}{l}\text { Unstandardized } \\
\text { Coefficients }\end{array}$} & \multirow{2}{*}{$\begin{array}{c}\text { Standardized } \\
\text { Coefficients } \\
\text { Beta } \\
\end{array}$} & \multirow[b]{2}{*}{$T$} & \multirow[b]{2}{*}{ Sig. } & \multicolumn{3}{|c|}{ Correlations } & \multirow{2}{*}{\multicolumn{2}{|c|}{$\begin{array}{l}\text { Collinearity } \\
\text { Statistics } \\
\text { Toler- } \\
\text { ance VIF } \\
\end{array}$}} \\
\hline & B & Std. Error & & & & $\begin{array}{l}\text { Zero- } \\
\text { order }\end{array}$ & $\begin{array}{l}\text { Par- } \\
\text { tial }\end{array}$ & Part & & \\
\hline 1 (Constant) & .492 & .018 & & 27.352 & .000 & & & & & \\
\hline Self - Efficacy & .142 & .026 & .418 & 5.386 & .000 & .418 & .418 & .418 & 1.000 & 1.000 \\
\hline
\end{tabular}

a. Dependent Variable: Entrepreneurship Intentions

The purpose of steps $1-3$ was to establish that zero-order relationships among the variables exist. If one or more of these relationships are nonsignificant, researchers usually conclude that mediation is not possible or likely (although this is not always true, MacKinnon, Fairchild, \& Fritz, 2007). A significant relationship from steps $1-3$, led to step 4 . In step 4 model, there was need to ascertain if a full or partial mediation occurred. According to Baron and Kenny (1986) a full mediation occurs if the effect of mediating variable (selfefficacy in this context) remains significant after controlling for independent variable (entrepreneurship education). On the other hand, a partial mediation is deemed to have occurred if the relationship between the independent variable and the dependent variable is still significant after controlling for the effects of the intervening variable (that is, both entrepreneurship education construct and self-efficacy significantly predict entrepreneurial intentions). The results of step 4 were presented as in Table 15.

Table 15. Regression Model with entrepreneurial intention as dependent variable

\begin{tabular}{cccccccccccc}
\hline & \multicolumn{1}{c}{$\begin{array}{c}\text { R } \\
\text { Model }\end{array}$} & $\begin{array}{c}\text { Adjusted } \\
\text { R }\end{array}$ & $\begin{array}{c}\text { Std. Error } \\
\text { of the }\end{array}$ & \multicolumn{9}{c}{ Change Statistics } \\
R Square & R Square & Estimate & Change & F Change & df1 & df2 & $\begin{array}{c}\text { Sig. F } \\
\text { Change }\end{array}$ & $\begin{array}{c}\text { Durbin- } \\
\text { Watson }\end{array}$ \\
\hline 1 & $.418^{a}$ & .175 & .169 & .20189 & .175 & 29.010 & 1 & 137 & .000 & 1.889 \\
\hline
\end{tabular}

a. Predictors: (Constant), Self- Efficacy

b. Dependent Variable: Entrepreneurial Intentions

Since the (Sig.-F $=000$ ), it means the regression model was good and, therefore, proceeded to interpret the results of the regression. The regression model, Table 17 , shows that $16.3 \%$ of the variance in intention is explained by self - efficacy. 
Further analysis was done to establish the relationship between selfefficacy, entrepreneurship education and entrepreneurial intention. The result is as shown in Table 16.

Table 16. Relationship between self -efficacy, entrepreneurship education and entrepreneurial intentions

\begin{tabular}{|c|c|c|c|c|c|c|c|c|c|c|}
\hline \multirow[b]{2}{*}{ Model } & \multicolumn{2}{|c|}{$\begin{array}{l}\text { Unstan- } \\
\text { dardized } \\
\text { Coefficients }\end{array}$} & \multirow[t]{2}{*}{$\begin{array}{l}\text { Standard- } \\
\text { ized Coef- } \\
\text { ficients }\end{array}$} & \multirow[b]{2}{*}{$T$} & \multirow[b]{2}{*}{ Sig. } & \multicolumn{3}{|c|}{ Correlations } & \multicolumn{2}{|c|}{$\begin{array}{l}\text { Collinearity } \\
\text { Statistics }\end{array}$} \\
\hline & B & $\begin{array}{l}\text { Std. } \\
\text { Error }\end{array}$ & & & & $\begin{array}{l}\text { Zero- } \\
\text { order }\end{array}$ & $\begin{array}{c}\text { Par- } \\
\text { tial }\end{array}$ & Part & Tolerance & VIF \\
\hline (Constant) & .491 & .018 & & 26.878 & .000 & & & & & \\
\hline Self - Efficacy & .139 & .033 & .409 & 4.200 & .000 & .418 & .339 & .327 & .638 & 1.566 \\
\hline $\begin{array}{l}\text { Entrepreneur- } \\
\text { ship Education }\end{array}$ & .005 & .034 & .014 & .147 & .883 & .261 & .013 & .011 & .638 & 1.566 \\
\hline
\end{tabular}

The coefficient Table 18 shows a statistically significant positive relationship between entrepreneurship self - efficacy and intention (Sig $=.000$ ) with a moderate contribution of $40.9 \%$ while there is statistically insignificant relationship between entrepreneurship education and intention (Sig. $=0.883$ ), contributing only $1.4 \%$ to the development of entrepreneurial intention. This result shows a full mediation of self-efficacy.

To cross check if a full mediation occurred, a step wise regression analysis was run. This was done to remove the variables which were not significant. The results were as shown in Tables 17, 18 and 19.

Table 17. Regression Model with entrepreneurial intention as dependent variable

\begin{tabular}{|c|c|c|c|c|c|c|c|c|c|c|}
\hline Model & $\mathbf{R}$ & R Square & $\begin{array}{l}\text { Adjusted } \\
\text { R Square }\end{array}$ & $\begin{array}{c}\text { Std. Error } \\
\text { of the } \\
\text { Estimate }\end{array}$ & $\begin{array}{c}\text { R Square } \\
\text { Change }\end{array}$ & $\begin{array}{l}\text { Change S } \\
\text { F Change }\end{array}$ & tatist & df2 & $\begin{array}{c}\text { Sig. F } \\
\text { Change }\end{array}$ & $\begin{array}{l}\text { Durbin- } \\
\text { Watson }\end{array}$ \\
\hline 1 & $.418^{\mathrm{a}}$ & .175 & .169 & .20189 & .175 & 29.010 & 1 & 137 & .000 & 1.889 \\
\hline
\end{tabular}

The model summary indicates that self - efficacy with Adj $R^{2}=0.169$ explain $16.9 \%$ of the variance in entrepreneurial intention. When enter method was used in running the regression, the results indicated the Adj $\mathrm{R}^{2}$ $=0.182(18.2 \%)$ meaning that all the variables taken together explain $18.2 \%$ of the variance in entrepreneurial intentions. Out of $18.2 \%$ of the variance in the entrepreneurial intention $16.9 \%$ was explained by variation in self efficacy alone leaving only $1.3 \%$ of the variance in intention to be explained 
by variations in content, objectives and method. It was concluded that self efficacy had mediating effect of $16.9 \%$ thus supporting the hypothesis..

Besides the Baron and Kenny (1986) four-step approach, a final test for mediation was carried out using hierarchical multiple regressions. The result brought out two levels of hierarchical models. The Tables 20 and 21 show the results. In model one, the result indicates self - efficacy as predictor and entrepreneurship intention as dependent variable. Model two, the predictors were indicated as self - efficacy, content, objectives and methods with intention as the dependent variable. The result indicates that there is a statistically significant positive mediation of self - efficacy of $17.5 \%$. On the other hand, model two indicates statistically insignificant relationship between the entrepreneurship education constructs and intentions, hence confirming the full mediation of self - efficacy. This result is consistent with the result obtained using Baron and Kenny (1986) four-step approach. The result is shown in Table 18.

Table 18. Regression Model with self - efficacy, methods, objectives and content as independent variables and entrepreneurial intention as dependent variable

\section{Change Statistics}

\begin{tabular}{|c|c|c|c|c|c|c|c|c|c|c|}
\hline odel & $\mathbf{R}$ & $\begin{array}{c}\mathbf{R} \\
\text { Squared }\end{array}$ & $\begin{array}{l}\text { Adjusted } \\
\text { R Square }\end{array}$ & $\begin{array}{l}\text { Std. Error } \\
\text { of the } \\
\text { Estimate }\end{array}$ & $\begin{array}{c}\text { R } \\
\text { Square } \\
\text { Change }\end{array}$ & F Change & df1 & df2 & $\begin{array}{c}\text { Sig. F } \\
\text { Change }\end{array}$ & $\begin{array}{l}\text { Durbin- } \\
\text { Watson }\end{array}$ \\
\hline 1 & $.418^{a}$ & .175 & .169 & .20189 & .175 & 29.010 & 1 & 137 & .000 & \\
\hline 2 & $.454^{b}$ & .206 & .182 & .20027 & .031 & 1.739 & 3 & 134 & .162 & 1.951 \\
\hline
\end{tabular}

a. Predictors: (Constant), Self - Efficacy

b. Predictors: (Constant), Self - Efficacy, Methods, Objectives, Content

c. Dependent Variable: Entrep.Intentions

The result of the regression further revealed the relationship between self-efficacy, content, objectives and methods with entrepreneurial intentions. The coefficient matrix results are presented as in Table 19.

Since the results indicate that self-efficacy has a mediating effect between the education construct (content, objective and method) and entrepreneurial intention, the hypothesis that the relationship between entrepreneurship education and entrepreneurial intention is mediated by entrepreneurial selfefficacy is confirmed. 
Table 19. Relationship between self- efficacy, content, objectives, and methods with entrepreneurial intentions

\begin{tabular}{|c|c|c|c|c|c|c|c|c|c|c|}
\hline \multirow[b]{2}{*}{ Model } & \multicolumn{5}{|c|}{$\begin{array}{l}\text { Unstandar- Standardi- } \\
\text { dized Coef- zed Coef- } \\
\text { ficients ficients }\end{array}$} & \multicolumn{3}{|c|}{ Correlations } & \multicolumn{2}{|c|}{$\begin{array}{l}\text { Collinearity } \\
\text { Statistics }\end{array}$} \\
\hline & B & $\begin{array}{l}\text { Std. } \\
\text { Error }\end{array}$ & Beta & $\mathrm{T}$ & Sig. & $\begin{array}{c}\text { Ze- } \\
\text { ro-or- } \\
\text { der }\end{array}$ & $\begin{array}{l}\text { Par- } \\
\text { tial }\end{array}$ & Part & Tolerance & VIF \\
\hline (Constant) & .492 & .018 & & 27.352 & .000 & & & & & \\
\hline Self - Efficacy & .142 & .026 & .418 & 5.386 & .000 & .418 & .418 & .418 & 1.000 & 1.000 \\
\hline (Constant) & .488 & .018 & & 26.873 & .000 & & & & & \\
\hline Self - Efficacy & .166 & .032 & .491 & 5.155 & .000 & .418 & .407 & .397 & .654 & 1.529 \\
\hline Content & -.039 & .021 & -.159 & -1.822 & .071 & .049 & -.155 & -.140 & .783 & 1.278 \\
\hline Objectives & -.003 & .019 & -.016 & -.185 & .854 & .174 & -.016 & -.014 & .794 & 1.259 \\
\hline Methods & .024 & .018 & .101 & 1.303 & .195 & .110 & .112 & .100 & .990 & 1.010 \\
\hline
\end{tabular}

\section{Discussion}

This study makes contribution to the literature by investigating and testing the statistical relationship between entrepreneurship education and entrepreneurial intention among university students, and the mediating effect of self-efficacy on the relationship between entrepreneurship education and entrepreneurial intentions among university students in Uganda. The author is not aware of efforts that have been made to empirically investigate this phenomena in the Ugandan context, even though there are numerous studies on the relationships between entrepreneurship education and entrepreneurial intentions, and between self-efficacy and entrepreneurship. The results indicate that the mediating effect of self-efficacy on the relationship between entrepreneurship education and entrepreneurial intention satisfies the conditions as suggested by Baron and Kenny (1986). This is true because the self-efficacy that resides in an individual can put that individual in a better position to a better position to be entrepreneurial.

The research results also indicate that students' exposure to entrepreneurship education has a positive effect on entrepreneurial selfefficacy and intentions. The correlation coefficient between self efficacy and intention is $(r=0.418, p<0.01)$; self- efficacy and entrepreneurship education is $(r=0.672, p<0.01)$; entrepreneurship education and intention is $(r=0.464$, $p<0.01)$. This is consistent with the result of path analysis which shows strong direct effect (.52) of self - efficacy on entrepreneurial intentions.

In relation to each of the hypotheses, support was found for the mediating effect of self-efficacy on entrepreneurial intentions: in examining 
the parameter estimates in the regression model, the self-efficacy dimensions were statistically significant to explain variance in entrepreneurial intentions. The result shows that in the absence of self-efficacy, entrepreneurship education and entrepreneurial intentions have weak relationship. However, in the presence of self-efficacy, entrepreneurship education and entrepreneurship intention among university students highly correlate as shown by the significant relationships existing among the variables measuring the two attributes.

However, on the other hand, self-efficacy does seem to explain some variation in entrepreneurial intentions as shown in the stepwise regression, even though it is relatively low. Partial mediation effect of self-efficacy was found on the relationship between entrepreneurship education and entrepreneurial intention. The results illustrate the importance of sources of self-efficacy as a conduit in enhancing the relationship between entrepreneurship education and entrepreneurial intention of students. This links well with the theory of planned behavior (TPB), especially the perceived behavioral control, which helps to understand how we can change the behavior of people (Ajzen, 1991). The perceived behavioral control came from Bandura's concept of self-efficacy. Individuals' appraisal of efficacy in a given domain is based in part on a judgment of their general self-regulatory capabilities. Thus, a topic such as entrepreneurship that entails study of macro performance that transcends specific situations, using the generic self-efficacy in combination with the entrepreneurial self-efficacy, appears justified.

\section{CONCLUSION}

This paper confirms that entrepreneurship education and self-efficacy play a fundamental role in enhancing entrepreneurial intentions. Entrepreneurship education is necessary condition but not sufficient to develop entrepreneurial intention unless combined with self - efficacy. Self-efficacy has a strong mediating effect between entrepreneurship education and entrepreneurial intentions among university students.

The entrepreneurial intentions of students are influenced directly by the students' self-efficacy and indirectly by entrepreneurship education. It can be concluded that entrepreneurship education can contribute significantly to development of students' entrepreneurial intention when mediated by selfefficacy. In other words, it can be stated thus: to be motivated to act, potential entrepreneurs must perceive themselves as capable and psychologically equipped to function. 


\section{Limitations of the study}

One limitation of this study is the use of only self-report measures. Survey data were self-reported; therefore study is prone to cognitive and motivational bias, for example, self-serving bias and social desirability. Since entrepreneurship is a charismatically charged term and carries a lot of social weight, to reduce social desirability in reporting high self-efficacy the survey instruction emphasized honesty for self assessment.

Although some of the constructs are conceptualized as self-reports, for example, self-efficacy, a second source of data would be particularly useful for other variables, such as the extent of learning from formal education. Class grades or performance on an objective test could be used in future research to gauge students' actual learning.

A second limitation is the Scope of the Study. The results of the study is limited to only three universities in Uganda by sample and method. Given the designs adopted in this study, nature of sampling done in a few universities and in one country and in more or less one region, generalization of our findings is limited to Uganda.

A third limitation is the student sample. The primary respondents were students facing an immediate career choice, for whom starting a business may be a realistic option. Also, even very early career intent is a good predictor. Nonetheless, they were still students with much variability among them; therefore it is difficult to draw any generalizations about them. This makes the identification of appropriate samples particularly important for studies that explore whether certain behaviors or beliefs can predict entrepreneurial behavior.

In sampling the university students, a proportionate stratified sampling was done leading to a highly skewed sample towards Makerere University Business School. A disproportionate stratified sampling that ensures reasonable representation of the other two universities would have been better.

Finally, study design itself is another limitation. A cross-sectional study design only offers a snap shot to explore whether static relationships exist and it diminishes any predictions in the long run. This is against background that entrepreneurship education issues and problems may be better investigated over a period of time with some degree of accuracy. However, this limitation was mitigated by using a triangulation approach to data collection to reduce the ambiguities in the data collected. 


\section{References}

Amin, M. E. (2005). Social Science Research; Conception, Methodology and Analysis. Kampala: Makerere University Printery.

Ardichvili, A., Cardozo, R., \& Ray, S. (2003). A theory of entrepreneurial opportunity identification and development. Journal of Business Venturing, 18, 105-123.

Bandura, A. (1997). Self-Efficacy. The Exercise of Control. New York: W.H. Freeman \& Company.

Bandura, A. (1986). The Social Foundations of Thought and Action. Englewood Cliffs, NJ: Prentice-Hall.

Bandura, A. (1982). Self-efficacy mechanism in human agency. American Psychologist, 37(2). 122-147.

Baron, R.M., \& Kenny, D.A. (1986). The moderator-mediator variable distinction in social psychological research: Conceptual, strategic and statistical considerations. Journal of Personality and Social Psychology, 51, 1173-1182.

Boyd, N.G., Vozikis, G.S. (1994). The influence of self-efficacy on the development of entrepreneurial intention and actions. Entrepreneurship Theory and Practice. Baylor University.

Chen, C.C., Greene, P.G., Crick, A. (1998). Does entrepreneurial self-efficacy distinguish entrepreneurs for managers?. Journal of Business Venturing, 13(4), 295-316.

Cox, L.W; Mueller, S.L; Moss, S.E. (2003). The Impact of Entrepreneurship Education on Entrepreneurial Self-Efficacy. International Journal of Entrepreneurship Education, 1(2), 229-247.

Creswell, J.W. (2003). Research Design - Quantitative, Qualitative and Mixed Methods Approach. Sage Publications, Inc. California, London and New York.

Gist, M.E., \& Mitchell, T.R. (1992). Self-efficacy: a theoretical analysis of its determinants and malleability. Academy of Management Review, 2(17), 183-211.

Gorman, G. \& Hanlon, D. (1997). Some research perspectives on entrepreneurship education, and enterprise education for small business management: a ten year literature review. International Small Business Journal, 15(3), 56-78.

Kolvereid, L., Moen, O. (1997). Entrepreneurship among business graduates: does a major in entrepreneurship make a difference?. Journal of European Industrial Training, 21(4), 154-160.

Krueger, N.F., \& Brazeal, D.V. (1994). Entrepreneurial potential and potential entrepreneurs. Entrepreneurship Theory and Practice, 18(3), 91-104.

Krueger, N.F. (1999). The cognitive infrastructure of opportunity emergence. Working Paper. National Council of Independent Scholars, Bozeman, MT.

Lucas, A.W; \& Cooper, S.Y; (2004). Enhancing self-efficacy to enable entrepreneurship: the case of CMI's connections. Cambridge, MA: MIT Sloan Working Paper 4489-04. 
MacKinnon, D.P., Fairchild, A.J. \& Fritz, M.S. (2007). Mediation analysis. Annual Review of Psychology, 58, 593-614.

Noel, T.W. (2002). Effects of entrepreneurship education on intent to open a business: an exploratory study. The Journal of Entrepreneurship Education, 5, 3-13.

Nunnaly, J. (1978). Psychometric Theory. New York: McGraw-Hill.

Oyugi, J.L. (2011). Contribution of Entrepreneurship Education to developing entrepreneurial self-efficacy and entrepreneurial intentions among university students in Uganda (unpublished PhD thesis). Nairobi: Kenyatta University.

Vancouver, J.B. (2002). Two studies examining the negative effect of selfefficacy on performance. Journal of Applied Psychology, 87(3), 506-516.

Varela, R., and Jimenez, J.E. (2001). The effect of entrepreneurship education in the universities of California. Frontiers of Entrepreneurship Research: Babson Conference Proceedings.

Wuensch, K.L. (2008). Conducting a Path Analysis with SPSS/AMOS. Greenville East Carolina University.

Zhao, H., Seibert, C. (2005). The moderating role of self-efficacy in the development of entrepreneurial intentions. Journal of Applied Psychology, 90(6), 1265- 1272.

\section{Abstrakt (in Polish)}

Ten artykuł został napisany na podstawie danych pochodzacych z obszernego badania przeprowadzonego przez J.L. Oyugi (2011). Badano wkład kształcenia w zakresie przedsiębiorczości dla rozwoju własnej skuteczności w działaniach gospodarczych $i$ intencji podjęcia takich działań wśród studentów wyższych uczelni w Ugandzie. Praca ta rozpoznaje rozwój i naukę kursów przedsiębiorczości w większości uniwersytetów w Ugandzie, majqcych na celu przygotowania absolwentów, którzy będq tworzyć miejsca pracy. W czasach, gdy podejmowane sq wysiłki w celu rozwiqzania bezrobocia wśród absolwentów poprzez główny nurt kształcenia w zakresie przedsiębiorczości w edukacji ponadpodstawowej i na poziomie szkół wyższych, niniejsza praca przedstawia jasne i aktualne wskazówki, jak tworzyć program nauczania przedsiębiorczości. Zaproponowano tu analizę ilościowq, w której edukacja w zakresie przedsiębiorczości i własnej skuteczności w roli przedsiębiorcy sq kluczowe w rozwijaniu intencji przedsiębiorczych studentów. Aby to zbadać, sformułowano dwie hipotezy. Dane zebrano za pomoca kwestionariusza ankiety elektronicznej, wypełnionej przez studentów, losowo wybranych spośród studentów III roku, którzy odbyli zajęcia z kursu przedsiębiorczości. Wyniki badań wykazały, że istniejq znaczqce relacje pomiędzy edukacja w zakresie przedsiębiorczości i zamierzeniem podjęcia działalności gospodarczej, podczas gdy poczucie własnej skuteczności okazało się częściowo pośredniczyć w edukacji z zakresu przedsiębiorczości i zamiarem podjęcia działań przedsiębiorczych.

Słowa kluczowe: kształcenie na rzecz przedsiębiorczości, poczucie własnej skuteczności jako przedsiębiorca, intencje przedsiębiorcze, mediacja, studenci. 


\section{Biographical note}

Dr. Jacob L. Oyugi is a Senior Lecturer in the Department of Management Science, School of Management and Entrepreneurship, Kyambogo University and Associate Consultant with Uganda Management Institute, Uganda. He earned his PhD from Kenyatta University, Nairobi. His research interest is entrepreneurship focusing on entrepreneurship education, training and development in universities. 